Check for updates

Cite this: RSC Adv., 2019, 9, 17425

Received 17th April 2019

Accepted 28th May 2019

DOI: $10.1039 / c 9 r a 02895 a$

rsc.li/rsc-advances

\section{Dimethylformamide-stabilised palladium nanoclusters catalysed coupling reactions of aryl halides with hydrosilanes/disilanes $\uparrow$}

\author{
Tatsuki Nagata, ${ }^{a}$ Takeru Inoue, ${ }^{a}$ Xianjin Lin, ${ }^{a}$ Shinya Ishimoto, ${ }^{a}$ Seiya Nakamichi, ${ }^{a}$ \\ Hideo Oka, ${ }^{a}$ Ryota Kondo, ${ }^{a}$ Takeyuki Suzuki ${ }^{b}$ and Yasushi Obora iD *a
}

\begin{abstract}
N,N-Dimethylformamide-stabilised Pd nanocluster (NC) catalysed cross-coupling reactions of hydrosilane/ disilane have been investigated. In this reaction, the coupling reaction proceeds without ligands with low catalyst loading. N,N-Dimethylacetamide is a crucial solvent in these reactions. The solvent effect was considered by various techniques, such as transmission electron microscopy, X-ray photoelectron spectroscopy, and thermogravimetric analysis. The Pd NCs can be recycled five times under both hydrosilane and disilane reaction conditions.
\end{abstract}

\section{Introduction}

Arylsilanes have attracted a great deal of interest in various fields. Silicon-containing molecules have unique and specific properties and various uses, such as in medicine, ${ }^{\mathbf{1}}$ in photonics, $^{2}$ and as organic intermediates. ${ }^{3}$ Conventional methods for arylsilane synthesis are unsatisfactory because of byproducts and side reactions. ${ }^{4}$ Accordingly, considerable attention has focused on their selective synthesis. ${ }^{5}$ Transition metal catalysed cross-coupling reactions between aryl halides and hydrosilanes or disilanes have emerged as selective and easy to handle protocols. However, these reactions are generally achieved using transition metal complexes, such as $\mathrm{Pd}^{6}$ and $\mathrm{Rh}^{7}$ complexes, with 1-5 mol\% of the catalyst. In addition, hydrosilanes act as weak reducing reagents ${ }^{8}$ and using them as coupling substrates inhibits reduction of aryl halides. Moreover, owing to the stability of the $\mathrm{Si}-\mathrm{Si}$ bond, disilanes show low reactivity for silylation reagents, so the coupling reactions require bulky phosphorus ligands. ${ }^{9}$

Metal nanoparticles (NPs) and nanoclusters (NCs) have unique physical and chemical properties. ${ }^{10}$ They are expected to show high catalytic performance owing to their stability, selectivity, activity, and recyclability. ${ }^{\mathbf{1 1 , 1 2}}$ On the other hand, colloidal nanocatalysts require removal of capping agent to access catalytically active surface. Stabilizing agents such as thiolates, phosphines, surfactants, and polymers, behaves a protect shell

${ }^{a}$ Department of Chemistry and Materials Engineering, Faculty of Chemistry, Materials and Bioengineering, Kansai University, Suita, Osaka 564-8680, Japan. E-mail: obora@ kansai-u.ac.jp

${ }^{b}$ Comprehensive Analysis Center, The Institute of Scientific and Industrial Research (ISIR), Osaka University, 8-1 Mihogaoka, Ibaraki, Osaka 567-0057, Japan

$\dagger$ Electronic supplementary information (ESI) available: Characterization and spectra. See DOI: 10.1039/c9ra02895a for reactant. ${ }^{13}$ We have reported a surfactant-free preparation of dimethylformamide (DMF)-stabilised transition-metal ( $\mathrm{Au}, \mathrm{Fe}$, Ir, $\mathrm{Cu}$, and Pd) NPs by the DMF reduction method. ${ }^{14}$ Among these NPs, Pd NCs have proven to be highly effective in various palladium-catalysed cross-coupling reactions, such as SuzukiMiyaura, Mizoroki-Heck, ${ }^{15 a}$ and Migita-Kosugi-Stille coupling reactions. ${ }^{15 b}$ DMF-stabilised $\mathrm{Fe}_{2} \mathrm{O}_{3}$ NPs also show high catalytic activity for hydrosilylation of unactivated terminal alkenes. ${ }^{\mathbf{1 6}}$ The $\mathrm{Pd}-\mathrm{Pt}-\mathrm{Fe}_{2} \mathrm{O}_{3}$ nanocatalyst has recently been reported for coupling aryl halides with hydrosilanes. However, the Pd monometallic catalyst shows low reactivity and causes decomposition. ${ }^{\mathbf{1 7}}$

In this paper, we describe DMF-stabilised palladium NCs catalysed coupling reactions of aryl halides with hydrosilanes/ disilanes to give arylsilanes with moderate to good yields. These reactions proceed at low catalyst loading under ligand and additive free conditions. In addition, the Pd NCs catalysts in both the hydrosilane/disilane reaction systems can be recycled at least five times.

\section{Results and discussion}

Initially, we chose to study the cross-coupling reaction between iodobenzene (1a) and dimethylphenylsilane (2a) using LiOAc as a base in DMF at $100{ }^{\circ} \mathrm{C}$. After $16 \mathrm{~h}$, dimethyldiphenylsilane (3a) was obtained in moderate yield (Table 1, entry 1 ). When we changed $\mathrm{N}$-dimethylacetamide (DMAc) solvent to the reaction, the yield increased to $80 \%$ (entry 2). The reaction was achieved by using low Pd loadings compared with the previously reported catalytic processes. ${ }^{6 \boldsymbol{b}, \boldsymbol{d}}$ During the course of the reaction, small amount of benzene ( $<10 \%$ yield) was observed as byproduct. The reaction was not accelerated in $N$-methyl-2-pyrrolidone (NMP) and toluene (entries 3 and 4). Various bases were tested. LiOAc gave the highest yield (entries 5-6). The use of 
Table 1 Optimisation of the coupling reaction conditions with hydrosilane $^{a}$

\begin{tabular}{|c|c|c|c|c|}
\hline Entry & Solvent & Base & Conv. (\%) & Yield $^{b}(\%)$ \\
\hline 1 & DMF & LiOAc & $>99$ & 52 \\
\hline 2 & DMAc & LiOAc & $>99$ & $80(75)$ \\
\hline 3 & NMP & LiOAC & $-^{c}$ & 41 \\
\hline 4 & Toluene & LiOAc & 66 & 7 \\
\hline 5 & DMAc & $\mathrm{NaOAc}$ & $>99$ & 68 \\
\hline 6 & DMAc & KOAc & $>99$ & 57 \\
\hline 7 & DMAc & $\mathrm{KO} t \mathrm{Bu}$ & $>99$ & 8 \\
\hline 8 & DMAc & None & $>99$ & 52 \\
\hline $9^{d}$ & DMAc & LiOAC & 97 & 9 \\
\hline
\end{tabular}

${ }^{a}$ Reaction conditions: 1a (1.0 mmol), $2 \mathrm{a}$ (3.0 mmol), Pd NCs (0.1 mol\%), and base $(1.0 \mathrm{mmol})$ in solvent $(1.0 \mathrm{~mL})$ at $100{ }^{\circ} \mathrm{C}$ for $16 \mathrm{~h} .{ }^{b}$ The conversion of 1a and yields were determined by gas chromatography (GC) analysis. The isolated yield is shown in parenthesis. ${ }^{c}$ Not determined due to overlapping of GC peaks. ${ }^{d} \mathrm{PdCl}_{2}$ was used as catalyst precursor.

$\mathrm{KO} t \mathrm{Bu}$ under these conditions gave the product in $8 \%$ yield along with intractable byproduct (by GC) (entry 7). The reaction also occurred in the absence of a base (entry 8). The use of $\mathrm{PdCl}_{2}$ under these conditions shows low catalytic activity (entry 9). To investigate the specific solvent effect, we prepared Pd NCs in DMF followed by a replacement of DMF on the Pd NCs by using DMAc by heating at $100{ }^{\circ} \mathrm{C}$ for $24 \mathrm{~h}$. A TEM image and the particle size distribution of the DMAc-displaced Pd NCs are shown in Fig. 1. The average particle size of $2 \mathrm{~nm}$ is the same as that of the prepared Pd NCs (Fig. 1).

${ }^{1}$ H-NMR spectroscopy, Fourier transform-infrared (FT-IR) spectroscopy, thermogravimetric (TG) analysis, and X-ray photoelectron spectroscopy (XPS) were performed to analyse the DMAc-substituted Pd NCs. From ${ }^{1} \mathrm{H}-\mathrm{NMR}$ analysis, several peaks around $8 \mathrm{ppm}$ in ${ }^{1} \mathrm{H}-\mathrm{NMR}$ assigned to formyl protons of DMF molecules on the Pd NCs. ${ }^{14 f, 15 a-c}$ The formyl group proton $(\delta=8.14 \mathrm{ppm})$ disappears after solvent displacement (Fig. S1 $\dagger$ ). FT-IR analysis (Fig. S2 $\dagger$ ) shows a peak at $1670 \mathrm{~cm}^{-1}$, which is attributed to the $n(\mathrm{C}=\mathrm{O})$ stretching vibration and indicates the presence of DMF and DMAc molecules. The thermal stability of the Pd NPs was investigated by TG analysis (Fig. 2). The TG
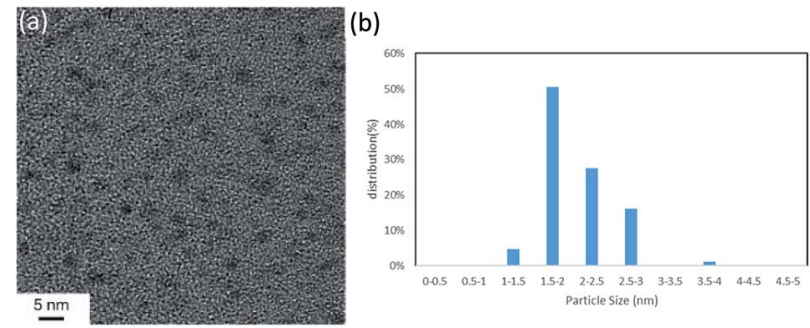

Fig. 1 (a) TEM image (scale bar $=5 \mathrm{~nm}$ ) and (b) nanoparticle size distribution of the DMAc-displaced Pd NCs.

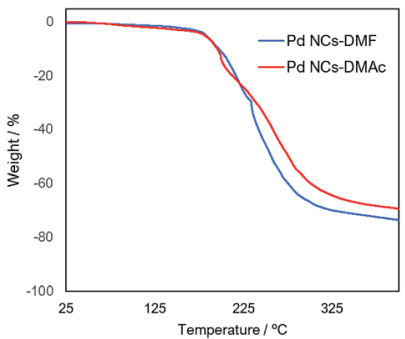

Fig. 2 TG analysis of Pd NCs-DMF (blue) and Pd NCs-DMAc (red).

curves in the range of $25{ }^{\circ} \mathrm{C}$ to $200{ }^{\circ} \mathrm{C}$ of the two Pd NCsprepared by DMF (Pd NCs-DMF) and the Pd NCs covered by DMAc (Pd NCs-DMAc) indicated similar charts. A difference was observed in the TG curves of the both Pd nanoclusters from above $200{ }^{\circ} \mathrm{C}$, suggesting that the two nanoparticles were protected by different molecules on the surface on the metal clusters (DMF and DMAc).

The surface states of the as-prepared Pd NCs and solventdisplaced Pd NCs with DMAc were determined by XPS. The binding energy positions of $\mathrm{Pd} 3 \mathrm{~d}_{5 / 2}$ and $\mathrm{Pd} 3 \mathrm{~d}_{3 / 2}$ are shown in Fig. 3. Peak FWHMs are described in Table $\mathrm{S} 1 . \dagger$ The other main peaks (C, O, and $\mathrm{N}$ ) are shown in Fig. S4-S6. $\dagger$ The main peaks of $\mathrm{Pd}$ at $338.8,337.2 \mathrm{eV}$ of $3 \mathrm{~d}_{5 / 2}$ and $344.0,342.1$ of $3 \mathrm{~d}_{3 / 2}$ was higher than that of bulk $\mathrm{Pd}\left(\mathrm{Pd} 3 \mathrm{~d}_{5 / 2} 335.1 \mathrm{eV}\right.$ and $\mathrm{Pd} 3 \mathrm{~d}_{3 / 2} 340.3$ eV). ${ }^{18,19}$ The $\mathrm{Pd} 3 \mathrm{~d}_{5 / 2}$ and $3 \mathrm{~d}_{3 / 2}$ spectrum of Pd NCs with DMF is shown in Fig. 3a. The DMAc Pd NCs have a broad peak ( $\mathrm{Pd} 3 \mathrm{~d}_{5 / 2}$ 343.7, $341.8 \mathrm{eV}$ and $\mathrm{Pd} 3 \mathrm{~d}_{3 / 2}$ 338.5, $336.6 \mathrm{eV}$ ) (Fig. 3b). A significant peak shift in Pd NCs with DMAc by increase of the measurement time (Fig. 3d). In contrast, the as-prepared Pd NCs remain unchanged (Fig. 3c). The changes in the two samples are caused by removal of the protective molecules on the surface. With irradiation by X-ray and sample heating, the protective molecules (DMF rigid protecting layer) are removed as the number of measurements increases. With elimination of the protective surface molecules, surface palladium is reduced. These data are associated with the TG analysis results, where DMAc displacement of the Pd NCs removes the capping molecules and results in easy access to the active sites.

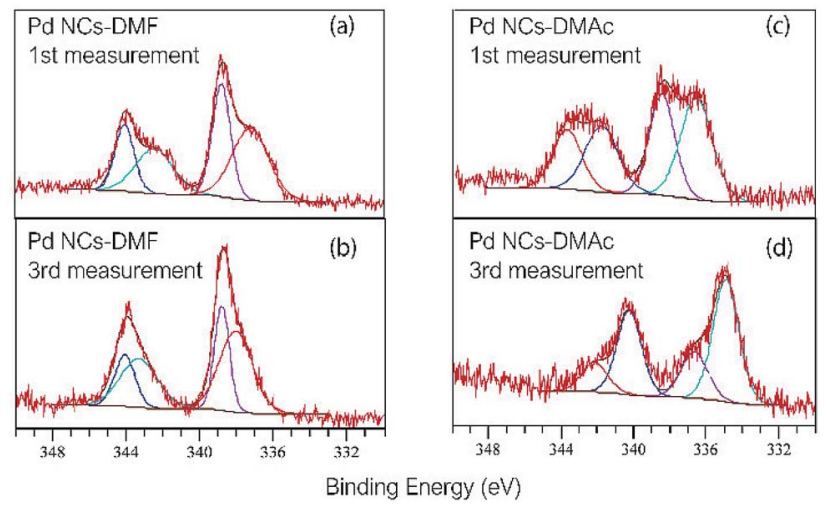

Fig. 3 XPS spectra of Pd NCs with DMF (a) at first measurement, (b) at third measurement, and Pd NCs with DMA which substituted from DMF (c) at 1st and (d) at 3rd measurement. 
Next, we investigated aryl halides bearing both electrondonating and electron-withdrawing substituents (Scheme 1). Electron-donating substrates (4-methyl and 4-methoxy, and 4tert-butyl) gave excellent yields ( $84 \%, 97 \%$, and $82 \%$ for $\mathbf{3 b}, \mathbf{3 c}$, and 3d, respectively). Electron withdrawing substrates were less effective (34\% and $42 \%$ for $\mathbf{3 e}$ and $\mathbf{3 f}$, respectively). Various silanes were investigated. The corresponding arylsilanes diphenylmethylsilane (3g), triethylsilane $(\mathbf{3 h})$, and triethoxysilane (3i) were obtained in $38 \%, 32 \%$, and $25 \%$ yield, respectively.

We wanted to extend the coupling reaction to disilanes. Hexamethyldisilane is readily available as a Rochow direct process byproduct. ${ }^{20}$ The reaction of iodobenzene with hexamethyldisilane at $120{ }^{\circ} \mathrm{C}$ afforded $\mathbf{5 a}$ in $70 \%$ yield (Table 2, entry 1). Various bases were examined. NaOAc showed the best performance (entries 2-5). The same solvent effect was observed for DMF and DMAc (entry 6). The presence of a base was necessary for the reaction (entry 7). The reaction by using $\mathrm{PdCl}_{2}$ as catalyst precursor and gave the product in $38 \%$ (entry 8 ).

Iodobenzene derivatives bearing electron-donating groups, such as $p$-methyl, $p$-methoxy, and $p$-tert-butyl groups, gave the corresponding products in good yields (Table 3, entries 2-4). Electron-withdrawing groups were less effective (entries 5-7). However, the reaction of bromo/chlorobenzene under these conditions was sluggish.

Based on the results and those reported in the literature, the plausible reaction mechanisms are shown in Scheme $\mathbf{5 7 . \dagger ^ { 2 1 }}$ Iodobenzene or hydrosilane oxidatively adds to the Pd NCs. The desired coupling product is obtained by the $\sigma$-bond metathesis reaction.

We investigated possible reuse of the catalyst. ${ }^{22}$ After the reaction, we performed annular dark field scanning transmission electron microscopy (ADF-STEM) and inductively coupled plasma-atomic emission spectroscopy (ICP-AES) analysis (Table S2 $†$ ). The particle size remained the same (Fig. 4).

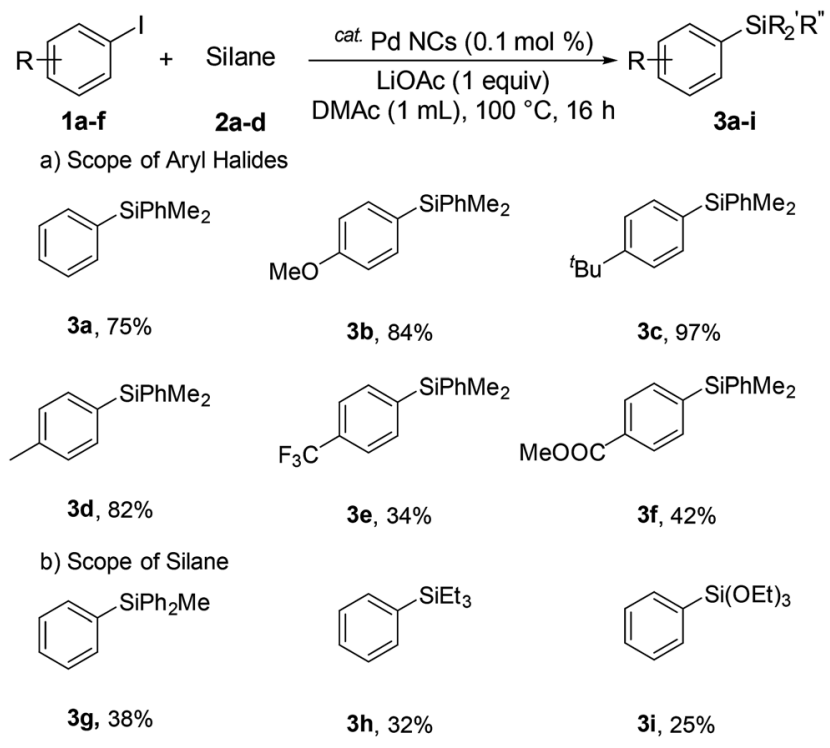

Scheme 1 Scope of various substrates.
Table 2 Optimisation of the arylsilylation condition with hexamethyldisilane ${ }^{a}$

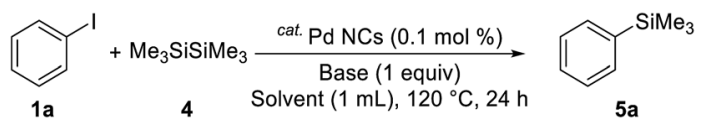

\begin{tabular}{lllll}
\hline Entry & Solvent & Base & Conv. (\%) & Yield $^{b}(\%)$ \\
\hline 1 & DMAc & LiOAc & $>99$ & 70 \\
2 & DMAc & NaOAc & $>99$ & $83(70)$ \\
3 & DMAc & $\mathrm{KF}$ & $>99$ & 73 \\
4 & DMAc & $\mathrm{Na}_{2} \mathrm{CO}_{3}$ & $>99$ & 78 \\
5 & DMAc & $\mathrm{KOtBu}$ & 89 & 27 \\
6 & DMF & NaOAc & $>99$ & 69 \\
7 & DMAc & None & 58 & 32 \\
$8^{c}$ & DMAc & NaOAc & 78 & 38
\end{tabular}

${ }^{a}$ Reaction conditions: $1 \mathrm{a}(1.0 \mathrm{mmol}), 4$ (3.0 mmol), Pd NCs $(0.1 \mathrm{~mol} \%)$, and base $(1.0 \mathrm{mmol})$ in solvent $(1.0 \mathrm{~mL})$ at $120{ }^{\circ} \mathrm{C}$ for $24 \mathrm{~h} .{ }^{b}$ The conversion of 1a and yields were determined by GC analysis. The isolated yield is shown in parenthesis. ${ }^{c} \mathrm{PdCl}_{2}$ was used as catalyst precursor.

Based on a previous study, the results suggest that the Pd NCs possess recyclability in the coupling reaction.

We investigated the recyclability of the Pd NCs (Fig. 5 and 6). After performing the reaction with the disilane system (Table 2, entry 2), the hexane layer was extracted using $8 \mathrm{~mL}$ of hexane five times. The hexane layer (containing the starting materials and products) was removed. The DMAc was evaporated from the residual DMAc layer containing Pd NCs and the residue was reused as the catalyst for the reaction under the same conditions (Table 2, entry 2). The Pd NCs gave good yields five times. We also tested the coupling reaction of aryl halide with hydrosilane (reaction conditions as in Table 1, entry 2). In the hydrosilane coupling reaction, the extraction solvent was modified. Product 3a and the starting materials were extracted using a mixed solvent (hexane : ethyl acetate $=95: 5$ ). The Pd NCs catalyst tolerated multiple cycles.

Table 3 Coupling Reaction of Aryl halides 1a with hexamethyldisilane ${ }^{a}$

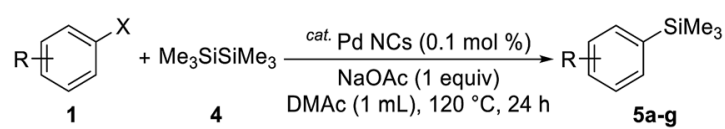

\begin{tabular}{lllll}
\hline Entry & $\mathrm{X}$ & $\mathrm{R}$ & Product & Yield $^{b}(\%)$ \\
\hline 1 & $\mathrm{I}$ & $\mathrm{H}$ & $\mathbf{5 a}$ & 70 \\
2 & & $p-\mathrm{Me}$ & $\mathbf{5 b}$ & 65 \\
3 & $p-\mathrm{OMe}$ & $\mathbf{5 c}$ & 73 \\
4 & & $p-{ }^{t} \mathrm{Bu}$ & $\mathbf{5 d}$ & 86 \\
5 & & $p-\mathrm{COMe}$ & $\mathbf{5 e}$ & 66 \\
6 & & $p-\mathrm{COOMe}$ & $\mathbf{5 f}$ & 59 \\
7 & & $p-\mathrm{CF}_{3}$ & $\mathbf{5 g}$ & 48 \\
8 & $\mathrm{Br}$ & $\mathrm{H}$ & $\mathbf{5 a}$ & $5^{c}$ \\
9 & $\mathrm{Cl}$ & $\mathrm{H}$ & $\mathbf{5 a}$ & Trace $^{c}$
\end{tabular}

${ }^{a}$ Reaction conditions: $1 \mathrm{a}(1.0 \mathrm{mmol}), 2 \mathrm{a}(3.0 \mathrm{mmol}), \mathrm{Pd}$ NCs $(0.1 \mathrm{~mol} \%)$, and base $(1.0 \mathrm{mmol})$ in DMAc $(1.0 \mathrm{~mL})$ at $120{ }^{\circ} \mathrm{C}$ for $24 \mathrm{~h} .{ }^{b}$ Isolated yield. ${ }^{c}$ GC yield. 

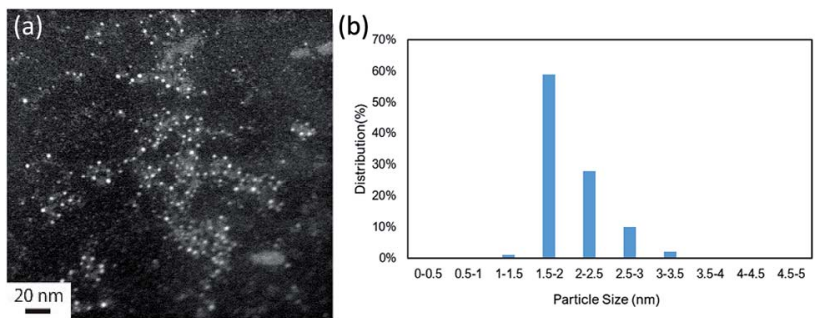

Fig. 4 (a) ADF-STEM image (scale bar $=20 \mathrm{~nm}$ ) and (b) particle size distribution of the Pd NCs after the reaction.
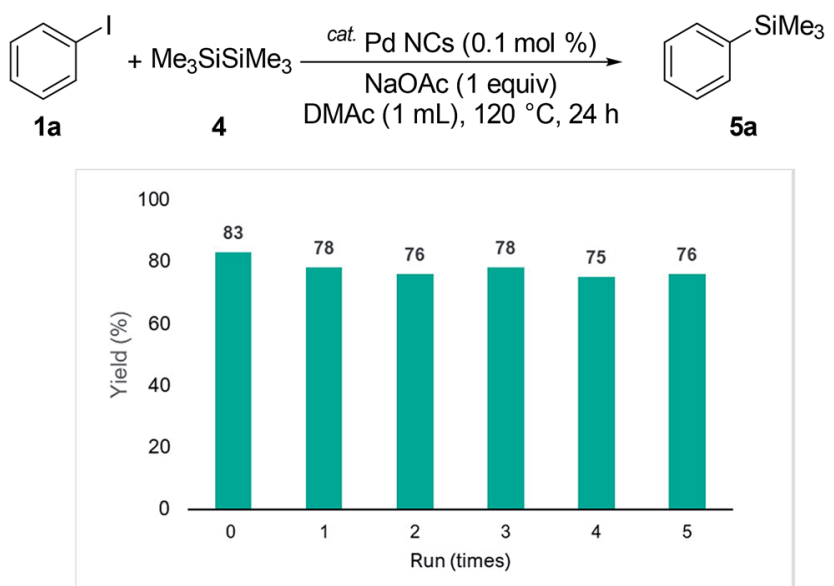

Fig. 5 Multiple catalyst recycling for coupling of iodobenzene with disilane (conditions as in Table 2, entry 2).

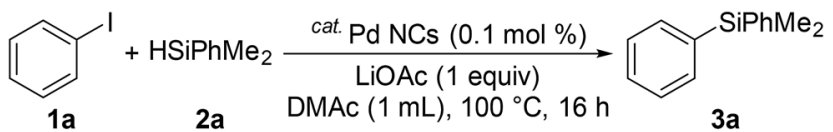

$1 \mathrm{a}$

$2 a$

MAc $(1 \mathrm{~mL}), 100^{\circ} \mathrm{C}, 16 \mathrm{~h}$

3a

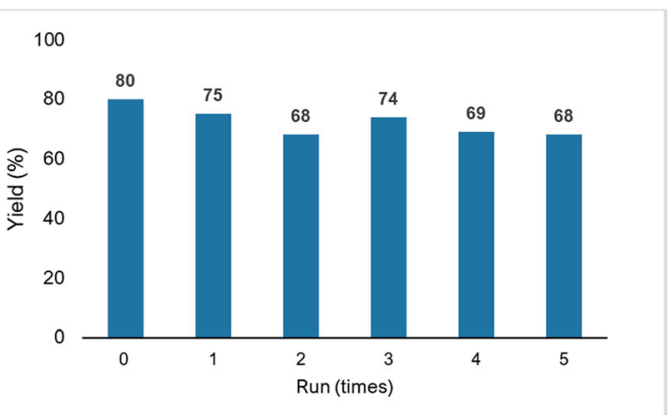

Fig. 6 Multiple catalyst recycling for coupling of iodobenzene with hydrosilane (conditions as in Table 1, entry 2).

\section{Conclusions}

We have developed Pd NCs catalytic system for silylation of aryl halides with hydrosilanes. The Pd NCs catalyst can be separated and reused at least five times without notable loss of the catalytic activity. The same catalyst can also be used for silylation of hexamethyldisilane. DMAs displacement enables easy access to the active sites of the Pd NCs. Further investigation of metal NPs as catalysts is underway.

\section{Experimental}

\section{General}

GC analysis was performed with a flame ionisation detector using a $0.22 \mathrm{~mm} \times 25 \mathrm{~m}$ capillary column (BP-5). The ${ }^{1} \mathrm{H}$ and ${ }^{13} \mathrm{C}$ NMR spectra were recorded at 400 and $100 \mathrm{MHz}$, respectively. The ${ }^{1} \mathrm{H}$ and ${ }^{13} \mathrm{C}$ NMR chemical shifts are reported in ppm with respect to the residual chloroform $\left({ }^{1} \mathrm{H} 7.26 \mathrm{ppm},{ }^{13} \mathrm{C} 77\right.$ $\mathrm{ppm})$. The products were characterised by ${ }^{1} \mathrm{H}$ NMR, ${ }^{13} \mathrm{C}$ NMR, and GC-MS. The TEM and STEM images were obtained with a JEOL JEM-ARM200F instrument at an accelerating voltage of $200 \mathrm{kV}$. Size distributions of nanoparticles were measured by counting 100 nanoparticles. ICP-AES was performed with a Shimadzu ICPS-8100 spectrometer. XPS analysis was performed with a ULVAC-PHI PHI5000 VersaProbe with Al Ka radiation. The measured spectra were calibrated by the $\mathrm{C} 1 \mathrm{~s}$ electron peak $(284.5 \mathrm{eV})$. TG analysis was performed with a Thermo Plus EVO device (Rigaku, Japan) at a heating rate of $10{ }^{\circ} \mathrm{C} \mathrm{min}^{-1}$ under nitrogen flow.

All of the synthesised compounds $\left(3 \mathbf{a},{ }^{23 a} 3 \mathbf{b},{ }^{23 a} 3 \mathbf{c},{ }^{23 a} 3 \mathbf{d},{ }^{23 b}\right.$ $3 \mathrm{e},{ }^{23 a} 3 \mathbf{f},{ }^{23 b} 3 \mathrm{~g},{ }^{23 e} 3 \mathbf{h},{ }^{23 c} 3 \mathbf{i},{ }^{23 d} 5 a^{24 a}{ }^{24 b},{ }^{24 c} 5 c^{24 c}, 5 d, 5 e,{ }^{24 b} 5 \mathbf{f},{ }^{24 d}$ and $\mathbf{5 g}^{\mathbf{2 4 b}}$ ) are known compounds and have been previously reported.

All of the starting materials were commercially available and used without further purification. The DMF-protected Pd NCs were prepared according to a previously reported method. ${ }^{15 a}$

(A) Preparation of the DMF-stabilised Pd NCs. DMF (50 $\mathrm{mL}$ ) was added to a $300 \mathrm{~mL}$ three-necked round bottom flask. The solution was preheated to $140{ }^{\circ} \mathrm{C}\left( \pm 2{ }^{\circ} \mathrm{C}\right)$ and stirred at $1500 \mathrm{rpm}$ for $5 \mathrm{~min}$. $\mathrm{PdCl}_{2}$ solution $(0.1 \mathrm{M}, 500 \mu \mathrm{L})$ was then added to the hot DMF solution, which was allowed to react for $10 \mathrm{~h}$ under stirring $(1500 \mathrm{rpm})$ at $140^{\circ} \mathrm{C}\left( \pm 2{ }^{\circ} \mathrm{C}\right)$. The resulting clear yellow solution was used as the $1 \mathrm{mM}$ Pd NCs solution in DMF. In prior to the catalytic reaction, DMF solvent was removed in vacuo, then the residue was dissolved in DMAc (50 $\mathrm{mL}$ ) and stirred the reaction mixture at $100{ }^{\circ} \mathrm{C}$ for $24 \mathrm{~h}$. Subsequent solvent evaporation in vacuo and the residue was used as Pd NCs-DMAc for the measurements and coupling reaction.

\section{Typical procedure}

(A) Reaction of aryl halides with hydrosilanes. A mixture of iodobenzene (1a, $204 \mathrm{mg}, 1 \mathrm{mmol}$ ), dimethylphenylsilane (2a, $409 \mathrm{mg}, 3 \mathrm{mmol}$ ), LiOAc (67 mg, $1 \mathrm{mmol}$ ), Pd NCs in DMAc (1 $\mathrm{mL}, 1 \mathrm{mM}$ ) as a catalyst, and solvent was stirred at $100{ }^{\circ} \mathrm{C}$ for $16 \mathrm{~h}$ in an Ar atmosphere. The product and substrate conversions and yields were estimated by GC from the peak areas based on an internal standard ( $n$-decane). 3 a was obtained in $80 \%$ yield. 3a was isolated by column chromatography [silica gel (230-400 mesh), $n$-hexane as eluent] in $75 \%$ yield (159 mg).

3a dimethyldiphenylsilane: colorless liquid, ${ }^{1} \mathrm{H}-\mathrm{NMR}(400$ $\left.\mathrm{MHz} ; \mathrm{CDCl}_{3} ; \mathrm{CDCl}_{3}\right) \delta:$ 7.57-7.54 (4H, m, Ph), 7.39-7.38 (6H, m, $\mathrm{Ph}), 0.59(6 \mathrm{H}, \mathrm{s}, \mathrm{Me}) ;{ }^{13} \mathrm{C}-\mathrm{NMR}\left(100 \mathrm{MHz} ; \mathrm{CDCl}_{3} ; \mathrm{CDCl}_{3}\right) \delta$ : $138.22(\mathrm{C}) 134.22(\mathrm{CH}), 129.11(\mathrm{CH}), 127.82(\mathrm{CH}),-2.42\left(\mathrm{CH}_{3}\right)$; GC-MS (EI) $\mathrm{m} / \mathrm{z}$ (relative intensity) 212(23) $[\mathrm{M}]^{+}, 197(100)$, 198(19), 105(9). 
3b dimethyl(phenyl)( $p$-tolyl)silane: colorless liquid, ${ }^{1} \mathrm{H}-\mathrm{NMR}$ $\left(400 \mathrm{MHz} ; \mathrm{CDCl}_{3} ; \mathrm{CDCl}_{3}\right) \delta: 7.57-7.55(2 \mathrm{H}, \mathrm{m}, \mathrm{Ph}), 7.48-7.46$ $(2 \mathrm{H}, \mathrm{m}), 7.39-7.38(3 \mathrm{H}, \mathrm{m}, \mathrm{Ph}), 7.23-7.21(2 \mathrm{H}, \mathrm{m}, \mathrm{Ph}), 2.39$ (3H, s, $\left.\mathrm{SiMe}_{2}\right), 0.58(6 \mathrm{H}, \mathrm{s}, \mathrm{Me}) ;{ }^{13} \mathrm{C}-\mathrm{NMR}\left(100 \mathrm{MHz} ; \mathrm{CDCl}_{3}\right.$; $\left.\mathrm{CDCl}_{3}\right) \delta: 138.96(\mathrm{C}), 138.50(\mathrm{C}), 134.53(\mathrm{C}), 134.23(\mathrm{CH}), 134.15$ $(\mathrm{CH}), 129.00(\mathrm{CH}), 128.65(\mathrm{CH}), 127.76(\mathrm{CH}), 21.45\left(\mathrm{CH}_{3}\right),-2.32$ $\left(\mathrm{CH}_{3}\right)$; GC-MS (EI) $\mathrm{m} / z$ (relative intensity) 226(18) [M] $]^{+}, 211(100)$, 212(21), 105(7).

3c (4-ethoxyphenyl)dimethyl(phenyl)silane: colorless liquid, ${ }^{1} \mathrm{H}-\mathrm{NMR}\left(400 \mathrm{MHz} ; \mathrm{CDCl}_{3} ; \mathrm{CDCl}_{3}\right) \delta: 7.53-7.44(7 \mathrm{H}, \mathrm{m}, \mathrm{Ph})$, 6.97-6.95 (2H, m, Ph), 3.85 (3H, s, OMe), 0.58 (6H, s, $\left.\mathrm{SiMe}_{2}\right) ;{ }^{13} \mathrm{C}-$ NMR (100 MHz; $\left.\mathrm{CDCl}_{3} ; \mathrm{CDCl}_{3}\right) \delta: 160.48(\mathrm{C}), 138.66(\mathrm{C}), 135.62$ $(\mathrm{CH}), 134.11(\mathrm{CH}), 128.97(\mathrm{CH}), 127.75(\mathrm{CH}), 113.58(\mathrm{CH}), 54.97$ $\left(\mathrm{CH}_{3}\right),-2.32\left(\mathrm{CH}_{3}\right)$; GC-MS (EI) $\mathrm{m} / z$ (relative intensity) $242(20)$ $[\mathrm{M}]^{+}, 227(100), 135(4)$.

3d (4-(tert-butyl)phenyl)dimethyl(phenyl)silane: colorless liquid, ${ }^{1} \mathrm{H}-\mathrm{NMR}\left(400 \mathrm{MHz} ; \mathrm{CDCl}_{3} ; \mathrm{CDCl}_{3}\right) \delta: 7.21-7.01(9 \mathrm{H}, \mathrm{m}$, $\mathrm{Ph}), 0.98(9 \mathrm{H}, \mathrm{s}, t \mathrm{Bu}), 0.21$ (6H, s, $\left.\mathrm{SiMe}_{2}\right) ;{ }^{13} \mathrm{C}-\mathrm{NMR}(100 \mathrm{MHz}$; $\mathrm{CDCl}_{3} ; \mathrm{CDCl}_{3}$ ) $\delta: 151.98$ (C), 138.46 (C), 134.59 (C), 134.15 (CH), $134.04(\mathrm{CH}), 128.99(\mathrm{CH}), 127.75(\mathrm{CH}), 124.77(\mathrm{CH}), 34.62(\mathrm{C})$, $31.22\left(\mathrm{CH}_{3}\right),-2.34\left(\mathrm{CH}_{3}\right)$; GC-MS (EI) $\mathrm{m} / z$ (relative intensity) 268(16) $[\mathrm{M}]^{+}, 253(100), 237(6), 105(10)$.

3e dimethyl(phenyl)(4-(trifluoromethyl)phenyl)silane: ${ }^{1} \mathrm{H}$ NMR (400 MHz; $\left.\mathrm{CDCl}_{3} ; \mathrm{CDCl}_{3}\right) \delta: 7.64-7.61(4 \mathrm{H}, \mathrm{m}, \mathrm{Ph}), 7.53-$ $7.52(2 \mathrm{H}, \mathrm{m}, \mathrm{Ph}), 7.41-7.38(3 \mathrm{H}, \mathrm{m} \mathrm{Ph}), 0.60\left(6 \mathrm{H}, \mathrm{s}, \mathrm{SiMe}_{2}\right) ;{ }^{13} \mathrm{C}-$ NMR (100 MHz; $\left.\mathrm{CDCl}_{3} ; \mathrm{CDCl}_{3}\right) \delta: 143.36\left(\mathrm{q},{ }^{4} J_{\mathrm{C}-\mathrm{F}}=1.0 \mathrm{~Hz}, \mathrm{CH}\right)$, $137.03(\mathrm{CH}), 134.41(\mathrm{CH}), 134.10(\mathrm{CH}), 130.99\left(\mathrm{q},{ }^{2} J \mathrm{C}_{\mathrm{F}}=\right.$ $32.2 \mathrm{~Hz}, \mathrm{CH}), 129.45(\mathrm{CH}), 127.97(\mathrm{CH}), 124.29\left(\mathrm{q},{ }^{3} J_{\mathrm{C}-\mathrm{F}}=3.7 \mathrm{~Hz}\right.$, $\mathrm{CH}), 124.19\left(\mathrm{q},{ }^{1} J_{\mathrm{C}-\mathrm{F}}=273.0 \mathrm{~Hz}, \mathrm{C}\right),-2.63\left(\mathrm{CH}_{3}\right)$; GC-MS (EI) $\mathrm{m} / \mathrm{z}$ (relative intensity) 280(4) $[\mathrm{M}]^{+}$, 265(100), 184(15).

3f methyl 4-(dimethyl(phenyl)silyl)benzoate: colorless liquid, ${ }^{1} \mathrm{H}-\mathrm{NMR}\left(400 \mathrm{MHz} ; \mathrm{CDCl}_{3} ; \mathrm{CDCl}_{3}\right) \delta: 8.00(2 \mathrm{H}, \mathrm{dd}, J=8.3$, $0.7 \mathrm{~Hz}, \mathrm{Ph}), 7.60(2 \mathrm{H}, \mathrm{dd}, J=8.3,0.7 \mathrm{~Hz}, \mathrm{Ph}), 7.51-7.49(2 \mathrm{H}, \mathrm{m}$, $\mathrm{Ph}$ ), 7.38-7.37 (3H, m, Ph), 3.92 (3H, s, OMe), 0.58 (6H, d, $J=$ $\left.0.6 \mathrm{~Hz}, \mathrm{SiMe}_{2}\right) ;{ }^{13} \mathrm{C}-\mathrm{NMR}\left(100 \mathrm{MHz} ; \mathrm{CDCl}_{3} ; \mathrm{CDCl}_{3}\right) \delta: 167.22$ (C), 144.63 (C), 137.28 (C), 134.13 (CH), 134.11 (CH), 130.49 (C), $129.34(\mathrm{CH}), 128.51(\mathrm{CH}), 127.91(\mathrm{CH}), 52.12\left(\mathrm{CH}_{3}\right),-2.61$ $\left(\mathrm{CH}_{3}\right)$; GC-MS (EI) $\mathrm{m} / z$ (relative intensity) $270(7)[\mathrm{M}]^{+}, 256(20)$, 255(100), 239(2).

$3 \mathrm{~g}$ methyltriphenylsilane: colorless liquid, ${ }^{1} \mathrm{H}-\mathrm{NMR}(400$ MHz; $\left.\mathrm{CDCl}_{3} ; \mathrm{CDCl}_{3}\right) \delta: 7.56-7.36(15 \mathrm{H}, \mathrm{m}, \mathrm{Ph}), 0.87(3 \mathrm{H}, \mathrm{s}$, SiMe); ${ }^{13} \mathrm{C}-\mathrm{NMR}\left(100 \mathrm{MHz} ; \mathrm{CDCl}_{3} ; \mathrm{CDCl}_{3}\right) \delta: 136.06$ (C), 135.25 $(\mathrm{CH}), 129.37(\mathrm{CH}), 127.83(\mathrm{CH}),-3.40\left(\mathrm{CH}_{3}\right)$; GC-MS (EI) $\mathrm{m} / \mathrm{z}$ (relative intensity) 274(5) $[\mathrm{M}]^{+}, 259(100), 180(12)$.

$3 \mathrm{~h}$ triethyl(phenyl)silane: colorless liquid, ${ }^{1} \mathrm{H}$ NMR $(400$ $\left.\mathrm{MHz} ; \mathrm{CDCl}_{3} ; \mathrm{CDCl}_{3}\right): \delta$ 7.50-7.35 (m, 2H, Ph), 7.34-7.25 (m, 3H, $\mathrm{Ph}), 0.96(\mathrm{t}, J=8.0 \mathrm{~Hz}, 9 \mathrm{H}, \mathrm{Me}), 0.79$ (q, $\left.J=7.2 \mathrm{~Hz}, 6 \mathrm{H}, \mathrm{SiCH}_{2}\right)$; ${ }^{13} \mathrm{C}$-NMR (100 MHz; $\mathrm{CDCl}_{3} ; \mathrm{CDCl}_{3}$ ): $\delta 137.8$ (C), 134.5 (CH), $129.0(\mathrm{CH}), 127.9(\mathrm{CH}), 7.7\left(\mathrm{CH}_{3}\right), 3.6\left(\mathrm{CH}_{2}\right)$; GC-MS (EI) $\mathrm{m} / \mathrm{z}$ (relative intensity) 192(6) [M] $]^{+}$, 163(59), 135(100), 107(77).

$3 \mathbf{i}$ triethoxy(phenyl)silane: colorless liquid, ${ }^{1} \mathrm{H}$ NMR $(400$ $\left.\mathrm{MHz} ; \mathrm{CDCl}_{3} ; \mathrm{CDCl}_{3}\right): \delta 7.68(\mathrm{~d}, J=6.4 \mathrm{~Hz}, 2 \mathrm{H}, \mathrm{Ph}), 7.34(\mathrm{~m}, 3 \mathrm{H}$, $\mathrm{Ph}), 3.87$ (q, $\left.J=7.2,6 \mathrm{H}, \mathrm{OCH}_{2}\right), 1.25(\mathrm{t}, J=6.89 \mathrm{H}, \mathrm{Me}) ;{ }^{13} \mathrm{C}-\mathrm{NMR}$ (100 MHz; $\left.\mathrm{CDCl}_{3} ; \mathrm{CDCl}_{3}\right): \delta 134.8(\mathrm{C}), 130.9(\mathrm{CH}), 130.4(\mathrm{CH})$, $127.9(\mathrm{CH}), 58.7\left(\mathrm{CH}_{2}\right), 18.2\left(\mathrm{CH}_{3}\right)$; GC-MS (EI) $\mathrm{m} / \mathrm{z}$ (relative intensity) $240(23)[\mathrm{M}]^{+}, 195(42), 145(100), 135(36)$.
(B) Reaction of aryl halides with disilanes. A mixture of iodobenzene (1a, $204 \mathrm{mg}, 1 \mathrm{mmol}$ ), hexamethyldisilane (4, $439 \mathrm{mg}, 3 \mathrm{mmol}$ ), NaOAc ( $82 \mathrm{mg}, 1.0 \mathrm{mmol}$ ), and Pd NCs in DMAc $(1.0 \mathrm{~mL}, 1 \mathrm{mM})$ as a catalyst was stirred at $120^{\circ} \mathrm{C}$ for $24 \mathrm{~h}$ in an $\mathrm{Ar}$ atmosphere. Conversion of the substrate and the yield of the product were estimated by GC from the peak areas based on an internal standard ( $n$-tridecane). 5 a was obtained in $83 \%$. 5a was isolated by column chromatography [silica gel (230-400 mesh), petroleum ether as eluent] in $70 \%$ yield $(105 \mathrm{mg}),{ }^{1} \mathrm{H}$ NMR (400 MHz; $\mathrm{CDCl}_{3} ; \mathrm{CDCl}_{3}$ ) 7.66-7.46 (2H, m, Ph), 7.40-7.33 $(3 \mathrm{H}, \mathrm{m}, \mathrm{Ph}), 0.27$ (9H, s, $\left.\mathrm{SiMe}_{3}\right) ;{ }^{13} \mathrm{C}-\mathrm{NMR}\left(100 \mathrm{MHz} ; \mathrm{CDCl}_{3}\right.$; $\left.\mathrm{CDCl}_{3}\right) \delta: 140.47(\mathrm{C}), 133.28(\mathrm{CH}), 128.75(\mathrm{CH}), 127.71(\mathrm{CH})$, $-1.16\left(\mathrm{CH}_{3}\right)$.; GC-MS (EI) $\mathrm{m} / z$ (relative intensity) $150(18)[\mathrm{M}]^{+}$, 136(12), 135(100).

5b trimethyl( $p$-tolyl)silane: colorless liquid, ${ }^{1} \mathrm{H}-\mathrm{NMR}(400$ $\left.\mathrm{MHz} ; \mathrm{CDCl}_{3} ; \mathrm{CDCl}_{3}\right): \delta 7.45(\mathrm{~d}, J=8.0 \mathrm{~Hz}, 2 \mathrm{H}, \mathrm{Ph}), 7.20(\mathrm{~d}, J=$ $7.6 \mathrm{~Hz}, 2 \mathrm{H}, \mathrm{Ph}$ ), 2.37 (s, 3H, Me), 0.27 (s, 9H, SiMe 3 ); ${ }^{13} \mathrm{C}-\mathrm{NMR}$ $\left(100 \mathrm{MHz} ; \mathrm{CDCl}_{3} ; \mathrm{CDCl}_{3}\right): \delta 138.6(\mathrm{C}), 136.8(\mathrm{C}), 133.3(\mathrm{CH})$, $128.6(\mathrm{CH}), 21.5\left(\mathrm{CH}_{3}\right),-1.1\left(\mathrm{CH}_{3}\right)$; GC-MS (EI) $\mathrm{m} / z$ (relative intensity) 164(13) $[\mathrm{M}]^{+}, 149(100), 121(9)$.

5c (4-methoxyphenyl)trimethylsilane: colorless liquid, ${ }^{1} \mathrm{H}-$ NMR (400 MHz; $\left.\mathrm{CDCl}_{3} ; \mathrm{CDCl}_{3}\right): \delta 7.20(\mathrm{~d}, J=8.8 \mathrm{~Hz}, 2 \mathrm{H}, \mathrm{Ph})$, $6.67(\mathrm{~d}, J=8.4 \mathrm{~Hz}, 2 \mathrm{H}, \mathrm{Ph}), 3.56$ (s, 3H, OMe), 0.00 (s, 9H, $\left.\mathrm{SiMe}_{3}\right) ;{ }^{13} \mathrm{C}-\mathrm{NMR}\left(100 \mathrm{MHz} ; \mathrm{CDCl}_{3} ; \mathrm{CDCl}_{3}\right.$ ): $\delta 162.2$ (C), 135.7 $(\mathrm{CH}), 132.2(\mathrm{C}), 114.4(\mathrm{CH}), 55.9\left(\mathrm{CH}_{3}\right), 0.00\left(\mathrm{CH}_{3}\right)$; GC-MS (EI) $\mathrm{m} / \mathrm{z}$ (relative intensity) 180(16) [M] $]^{+}, 165(100), 135(9)$.

5d (4-(tert-butyl)phenyl)trimethylsilane: white solid, m.p. $77.5-78,{ }^{1} \mathrm{H}-\mathrm{NMR}\left(400 \mathrm{MHz} ; \mathrm{CDCl}_{3} ; \mathrm{CDCl}_{3}\right): \delta 7.49(\mathrm{~d}, J=8.4 \mathrm{~Hz}$, $2 \mathrm{H}, \mathrm{Ph}), 7.41$ (d, $J=8.0 \mathrm{~Hz}, 2 \mathrm{H}, \mathrm{Ph}), 1.34$ (s, 9H, Me), 0.27 (s, 9H, $\left.\mathrm{SiMe}_{3}\right) ;{ }^{13} \mathrm{C}-\mathrm{NMR}\left(100 \mathrm{MHz} ; \mathrm{CDCl}_{3} ; \mathrm{CDCl}_{3}\right.$ ): $\delta 151.7$ (C), 136.9 (C), $133.2(\mathrm{CH}), 124.7(\mathrm{CH}), 34.6(\mathrm{C}), 31.2\left(\mathrm{CH}_{3}\right),-1.06\left(\mathrm{CH}_{3}\right)$; GC-MS (EI) $\mathrm{m} / \mathrm{z}$ (relative intensity) 206(12) [M] $]^{+}$, 191(100), 176(7).

5e 1-(4-(trimethylsilyl)phenyl)ethan-1-one: colorless liquid, ${ }^{1} \mathrm{H}-\mathrm{NMR}\left(400 \mathrm{MHz} ; \mathrm{CDCl}_{3} ; \mathrm{CDCl}_{3}\right) \delta: 7.92-7.91(2 \mathrm{H}, \mathrm{m}, \mathrm{Ph})$, 7.63-7.61 (2H, m, Ph), 2.60 (3H, s, COMe), 0.29 (9H, s, $\left.\mathrm{SiMe}_{3}\right)$; ${ }^{13} \mathrm{C}-\mathrm{NMR}\left(100 \mathrm{MHz} ; \mathrm{CDCl}_{3} ; \mathrm{CDCl}_{3}\right.$ ) $\delta: 198.33$ (C), 147.21 (C), 137.17 (C), $133.48(\mathrm{CH}), 127.19(\mathrm{CH}), 26.58\left(\mathrm{CH}_{3}\right),-1.38\left(\mathrm{SiMe}_{3}\right)$; GC-MS (EI) $m / z$ (relative intensity) 192(14) [M] $]^{+}, 177(100), 162(1)$, 119(7).

5f methyl 4-(trimethylsilyl)benzoate: colorless liquid, ${ }^{1} \mathrm{H}-$ NMR $\left(400 \mathrm{MHz} ; \mathrm{CDCl}_{3} ; \mathrm{CDCl}_{3}\right) \delta: 7.99(2 \mathrm{H}, \mathrm{d}, J=8.3 \mathrm{~Hz}, \mathrm{Ph})$, $7.59(2 \mathrm{H}, \mathrm{d}, J=8.2 \mathrm{~Hz}, \mathrm{Ph}), 3.92(3 \mathrm{H}, \mathrm{s}, \mathrm{OMe}), 0.29(9 \mathrm{H}, \mathrm{s}$, $\left.\mathrm{SiMe}_{3}\right) ;{ }^{13} \mathrm{C}-\mathrm{NMR}\left(100 \mathrm{MHz} ; \mathrm{CDCl}_{3} ; \mathrm{CDCl}_{3}\right) \delta: 167.28(\mathrm{C}), 146.84$ (C), $133.27(\mathrm{CH}, \mathrm{s}), 130.19(\mathrm{C}), 128.44(\mathrm{CH}), 52.09\left(\mathrm{CH}_{3}\right),-1.34$ $\left(\mathrm{CH}_{3}\right)$; GC-MS (EI) $\mathrm{m} / \mathrm{z}$ (relative intensity) 208(5) $[\mathrm{M}]^{+}, 193(100)$, 133(14).

$\mathbf{5 g}$ trimethyl(4-(trifluoromethyl)phenyl)silane: ${ }^{1} \mathrm{H}$-NMR (400 $\left.\mathrm{MHz}, \mathrm{CDCl}_{3} ; \mathrm{CDCl}_{3}\right): \delta 7.64(\mathrm{~d}, J=7.6 \mathrm{~Hz}, 2 \mathrm{H}, \mathrm{Ph}), 7.59(\mathrm{~d}, J=$ $8.0 \mathrm{~Hz}, 2 \mathrm{H}, \mathrm{Ph}), 0.30$ (s, 9H, $\left.\mathrm{SiMe}_{3}\right) ;{ }^{13} \mathrm{C}-\mathrm{NMR}\left(100 \mathrm{MHz} ; \mathrm{CDCl}_{3}\right.$; $\left.\mathrm{CDCl}_{3}\right): \delta 145.6(\mathrm{C}), 133.8(\mathrm{CH}), 130.8(\mathrm{q}, J=31.6 \mathrm{~Hz}, \mathrm{C}), 124.3$ (q, $J=270.2 \mathrm{~Hz}, \mathrm{C}), 124.2(\mathrm{q}, J=3.9 \mathrm{~Hz} \mathrm{CH}),-1.41\left(\mathrm{CH}_{3}\right) \mathrm{GC}-\mathrm{MS}$ (EI) $\mathrm{m} / \mathrm{z}$ (relative intensity) 218(6) $[\mathrm{M}]^{+}, 203(100), 189(0.60)$.

\section{Preparation of the TEM sample}

(A) Pd NCs-DMAc (before the reaction). After preparation the Pd NCs, Solvent DMF was displaced DMAc. The DMAc Pd 
NCs solution was stirred at $100{ }^{\circ} \mathrm{C}, 24 \mathrm{~h}$, then they were diluted with $3 \mathrm{~mL}$ of ethanol and added dropwise onto the TEM grid (Cu).

(B) Pd NCs-DMAc (after the reaction). After the reaction under the conditions given in Table 2, entry 2, the reaction mixture was extracted with a mixed solvent [hexane : ethyl acetate (99:1), $5 \mathrm{~mL}, 5$ times] to remove 5a. DMAc was removed by evaporation under high vacuum and then redispersed in ethanol.

\section{Recycling experiment}

(A) Reaction of aryl halides with hydrosilanes. The Pd NCs were separated from 3a using a mixed solvent (hexane : ethyl acetate $=95: 5,5 \mathrm{~mL}$, ten times, upper phase containing 3a). The Pd NCs remained in the DMAc solvent (bottom phase). Conversion of the substrate and the yield of the product were calculated from their GC peak areas based on an internal standard (n-decane). The DMAc solution containing the Pd NCs was filtered through a cotton plug to remove the Pd NCs from the DMAc solution. DMAc was removed under vacuum and the residue was redissolved in DMAc $(1 \mathrm{~mL})$. Pd NCs in DMF were used for the next catalytic reaction under the reaction conditions given in Table 1, entry 2 by adding iodobenzene (1a, $109 \mathrm{mg}, 1.0 \mathrm{mmol}$ ), dimethylphenylsilane (2a, $409 \mathrm{mg}, 3.0$ $\mathrm{mmol}$ ), and LiOAc (67 mg, $1.0 \mathrm{mmol}$ ).

(B) Reaction of aryl halides with disilanes. The Pd NCs were separated from 5a using hexane ( $5 \mathrm{~mL}$, ten times). The upper phase contained 5a. The Pd NCs remained in the DMAc solvent (bottom phase). Conversion of the substrate and the yield of the product were calculated from their GC peak areas based on an internal standard ( $n$-tridecane). The DMAc solution containing the Pd NCs was filtered through a cotton plug to remove the Pd NCs from the DMAc solution. DMAc was removed under vacuum and the residue was redissolved in DMAc $(1 \mathrm{~mL})$. The Pd NCs in DMAc were used for the next catalytic reaction under the reaction conditions given in Table 2, entry 2 by adding iodobenzene (1a, $204 \mathrm{mg}, 1.0 \mathrm{mmol}$ ), hexamethyldisilane (4, $409 \mathrm{mg}, 3.0 \mathrm{mmol}$ ), and NaOAc (82 mg, $1.0 \mathrm{mmol})$.

\section{Conflicts of interest}

There are no conflicts to declare.

\section{Acknowledgements}

This work was supported by the "Development of Innovative Catalytic Processes for Organosilicon Functional Materials" project (PL: K. Sato, AIST) from the New Energy and Industrial Technology Development Organization (NEDO). We thank the members of the Comprehensive Analysis Center, SANKEN (ISIR), Osaka University, for TEM, ICP-AES analyses.

\section{Notes and references}

1 (a) J. Wang, C. Ma, Y. Wu, R. A. Lamb, L. H. Pinto and W. F. Degrado, J. Am. Chem. Soc., 2011, 133, 13844; (b) A. K. Franz and S. O. Wilson, J. Med. Chem., 2013, 56, 388.
2 (a) M. Shimizu, K. Mochida and T. Hiyama, Angew. Chem., Int. Ed., 2008, 47, 9760; (b) X. M. Liu, C. He, J. Huang and J. Xu, Chem. Mater., 2005, 17, 434; (c) G. W. Kim, D. R. Yang, Y. C. Kim, H. I. Yang, J. G. Fan, C. H. Lee, K. Y. Chai and J. H. Kwon, Dyes Pigm., 2017, 136, 8; (d) H. Inubushi, Y. Hattori, Y. Yamanoi and H. Nishihara, $J$. Org. Chem., 2014, 79, 2974; (e) N. You, C. G. An, J. J. Kim and Y. P. Soo, J. Org. Chem., 2007, 72, 6241.

3 (a) P. Somfai and B. Seashore-Ludlow, Organosilicon Reagents: Vinyl-, Alkynyl-, and Arylsilanes, Elsevier Ltd., 2014; (b) T. Komiyama, Y. Minami and T. Hiyama, ACS Catal., 2017, 7, 631; (c) A. S. Manoso and P. DeShong, J. Org. Chem., 2001, 66, 7449.

4 (a) S. Luliński and J. Serwatowski, J. Org. Chem., 2003, 68, 9384; (b) A. S. Manoso, C. Ahn, A. Soheili, C. J. Handy, R. Correia, W. M. Seganish and P. DeShong, J. Org. Chem., 2004, 69, 8305.

5 Z. Xu, W. S. Huang, J. Zhang and L. W. Xu, Synthesis, 2015, 47, 3645 .

6 (a) H. Guo, X. Chen, C. Zhao and W. He, Chem. Commun., 2015, 51, 17410; (b) Y. Yamanoi, J. Org. Chem., 2005, 70, 9607; (c) N. Iranpoor, H. Firouzabadi and R. Azadi, J. Organomet. Chem., 2010, 695, 887; (d) M. Murata, K. Suzuki, S. Watanabe and Y. Masuda, J. Org. Chem., 1997, 62, 8569.

7 (a) M. Murata, M. Ishikura, M. Nagata, S. Watanabe and Y. Masuda, Org. Lett., 2002, 4, 1843; (b) Y. Yamanoi and H. Nishihara, Tetrahedron Lett., 2006, 47, 7157-7161; (c) Y. Yamanoi and H. Nishihara, J. Org. Chem., 2008, 73, 6671; (d) M. Murata, H. Yamasaki, K. Uogishi, S. Watanabe and Y. Masuda, Synthesis, 2007, 2944.

8 (a) J. Y. Corey, Chem. Rev., 2011, 111, 863; (b) R. Boukherroub, C. Chatgilialoglu and G. Manuel, Organometallics, 2002, 15, 1508.

9 (a) T. Iwasawa, T. Komano, A. Tajima, M. Tokunaga, Y. Obora, T. Fujihara and Y. Tsuji, Organometallics, 2006, 25, 4665; (b) J. Jang, S. Byun, B. M. Kim and S. Lee, Chem. Commun., 2018, 54, 3492; (c) E. Shirakawa, T. Kurahashi, H. Yoshida and T. Hiyama, Chem. Commun., 2000, 1895; (d) E. McNeill, T. E. Barder and S. L. Buchwald, Org. Lett., 2007, 9, 3785.

10 (a) Y. Lu and W. Chen, Chem. Soc. Rev., 2012, 41, 3594; (b) L. Zhang and E. Wang, Nano Today, 2014, 9, 132; (c) A. Mathew and T. Pradeep, Part. Part. Syst. Charact., 2014, 31, 1017.

11 (a) S. Campisi, M. Schiavoni, C. Chan-Thaw and A. Villa, Catalysts, 2016, 6, 185; (b) Y. Dai, Y. Wang, B. Liu and Y. Yang, Small, 2015, 11, 268; (c) T. Nagata, Y. Adachi and Y. Obora, Synlett, 2018, 29, 2655; (d) Y. Adachi, H. Kawasaki, T. Nagata and Y. Obora, Chem. Lett., 2016, 45, 1457.

12 (a) A. Bej, K. Ghosh, A. Sarkar and D. W. Knight, RSC Adv., 2016, 6, 11446; (b) D. Roy and Y. Uozumi, Adv. Synth. Catal., 2018, 360, 602; (c) C. Deraedt and D. Astruc, Acc. Chem. Res., 2014, 47, 494.

13 (a) W. Huang, Q. Hua and T. Cao, Catal. Lett., 2014, 144, 1355; (b) Z. Niu and Y. Li, Chem. Mater., 2014, 26, 72. 
14 (a) H. Kawasaki, Nanotechnol. Rev., 2013, 2, 5; (b) I. PastorizoSantos and L. M. Liz-Marzán, Adv. Funct. Mater., 2009, 19, 679; (c) H. Oka, K. Kitai, T. Suzuki and Y. Obora, RSC Adv., 2017, 7, 22869; (d) K. Oikawa, S. Itoh, H. Yano, H. Kawasaki and Y. Obora, Chem. Commun., 2017, 53, 1080; (e) Y. Isomura, T. Narushima, H. Kawasaki, T. Yonezawa and Y. Obora, Chem. Commun., 2012, 48, 3784; $(f)$ H. Yamamoto, H. Yano, H. Kouchi, Y. Obora, R. Arakawa and H. Kawasaki, Nanoscale, 2012, 4, 4148.

15 (a) M. Hyotanishi, Y. Isomura, H. Yamamoto, H. Kawasaki and Y. Obora, Chem. Commun., 2011, 47, 5750; (b) H. Yano, Y. Nakajima and Y. Obora, J. Organomet. Chem., 2013, 745746, 258; (c) K. Onishi, K. Oikawa, H. Yano, T. Suzuki and Y. Obora, $R S C A d v ., 2018,8,11324$; (d) S. Asada, A. Nito, Y. Miyagi, J. Ishida, Y. Obora and F. Sanda, Macromolecules, 2017, 50, 4083.

16 R. Azuma, S. Nakamichi, J. Kimura, H. Yano, H. Kawasaki, T. Suzuki, R. Kondo, Y. Kanda, K. I. Shimizu, K. Kato and Y. Obora, ChemCatChem, 2018, 10, 2378.

17 J. Jang, S. Byun, B. M. Kim and S. Lee, Chem. Commun., 2018, 54, 3492.

18 (a) M. G. Mason, Phys. Rev. B: Condens. Matter Mater. Phys., 1983, 27, 748; (b) G. K. Wertheim, S. B. DiCenzo and D. N. E. Buchanan, Phys. Rev. B: Condens. Matter Mater. Phys., 1986, 33, 5384.

19 (a) M. Chiba, M. N. Thanh, Y. Hasegawa, Y. Obora, H. Kawasaki and T. Yonezawa, J. Mater. Chem. C, 2015, 3,
514; (b) M. Ren, Y. Jin, W. Chen and W. Huang, J. Phys. Chem. C, 2015, 119, 27588.

20 (a) E. G. Rochow, J. Am. Chem. Soc., 1945, 67, 963; (b) W. J. Ward, A. Ritzer, K. M. Carroll and J. W. Flock, J. Catal., 1986, 100, 240.

21 J. Cao, Y.-M. Cui, Z. Xu, J. Zhang, L.-W. Xu, Z.-J. Zheng and J.-Z. Xu, Chem.-Asian J., 2017, 12, 1749.

22 (a) Á. Molnár, Chem. Rev., 2011, 111, 2251; (b) Á. Molnár and A. Papp, Coord. Chem. Rev., 2017, 349, 1.

23 (a) M. Uchiyama, Y. Kobayashi, T. Furuyama, S. Nakamura, Y. Kajihara, T. Miyoshi, T. Sakamoto, Y. Kondo and K. Morokuma, J. Am. Chem. Soc., 2008, 130, 472; (b) H. Guo, X. Chen, C. Zhao and W. He, Chem. Commun., 2015, 51, 17410-17412; (c) N. Iranpoor, H. Firouzabadi and R. Azadi, J. Organomet. Chem., 2010, 695, 887; (d) M. Murata, H. Yamasaki, T. Ueta, M. Nagata, M. Ishikura, S. Watanabe and Y. Masuda, Tetrahedron, 2007, 63, 4087; (e) N. Tsukada and J. F. Hartwig, J. Am. Chem. Soc., 2005, 127, 5022.

24 (a) H. Inubushi, H. Kondo, A. Lesbani, M. Miyachi, Y. Yamanoi and H. Nishihara, Chem. Commun., 2013, 49, 134; (b) M. Tobisu, Y. Kita, Y. Ano and N. Chatani, J. Am. Chem. Soc., 2008, 130, 15982; (c) A. P. Lothian, C. A. Ramsden, M. M. Shaw and R. G. Smith, Tetrahedron, 2011, 67, 2788; (d) M. Tobisu, Y. Kita and N. Chatani, J. Am. Chem. Soc., 2006, 128, 8152. 